Rozprawy Komisji Językowej ŁTN, t. LXVII, 2019

ISSN 0076-0390; e-ISSN 2450-9310

https://doi.org/10.26485/RKJ/2019/67/12

Atta Krawczuk*

(D) https://orcid.org/0000-0003-4087-3562

\title{
ŚWIADOMOŚĆ JĘZYKOWA OSÓB POLSKIEGO POCHODZENIA NA UKRAINIE W ZAKRESIE UŻYWANIA WYBRANYCH FORM GRZECZNOŚCIOWYCH
}

\author{
LANGUAGE AWARENESS OF PEOPLE OF POLISH DESCENT LIVING \\ IN UKRAINE IN THE USE OF SOME POLITE FORMS
}

The author of the article analyzes typical deviations from general Polish norms in the Polish language of people declaring Polish descent and living in Ukraine. The study is based both on texts and three types of questionnaires and concerns the use of some polite forms: the address phrases pan/pani + imię; congratulations and wishes containing words witać and pozdrawiać; constructions with unnecessary words pan/pani used before proper name in referential structures in press texts. The research material shows that speakers' language awareness considered as a competence is very low. Data on language awareness considered as beliefs about studied forms were obtained by means of the material of a separate questionnaire and revealed the reasons the speakers use these structures.

Keywords: Polish language in Ukraine, polite forms, language awareness, questionnaire

Słowa kluczowe: język polski na Ukrainie, formy grzecznościowe, świadomość językowa, ankieta

\section{WPROWADZENIE}

Obiektem badań przedstawionych w tym artykule jest polszczyzna osób (głównie młodych) mieszkających na Ukrainie, deklarujących swoje polskie pochodzenie. Na określenie ich języka używane są bardziej lub mniej trafne terminy, będące thumaczeniem angielskiego heritage language: język odziedziczony [zob. np. Lipińska, Seretny, 2012; 2016 i - w ślad za nimi - większość współczesnych polskich glottodydaktyków], język dziedziczony [np. Dembowska-Wosik, 2011; Martowicz, 2014], język przodków [Dzięgiel, 2017].

* Narodowy Uniwersytet Lwowski im. Iwana Franki, Wydział Filologiczny, Katedra Filologii Polskiej, ul. Uniwersytecka 1, 79000 Lwów, Ukraina; e-mail: allakrawczuk@gmail.com. 
Termin język odziedziczony, jak piszą Ewa Lipińska i Anna Seretny, bliski jest zakresowo terminowi język domowy, określającemu:

[...] słuchowo-ustny kod stosowany przez członków rodziny [poza Polską - przyp. A.K.] w podstawowych domenach [...], obejmujących przede wszystkim dom, rodzinę, kośció i/lub społeczność etniczną [Lipińska, Seretny, 2013, s. 2] $]^{1}$.

Jednak język odziedziczony, w odróżnieniu od języka domowego:

[...] ewoluuje, ponieważ jest uczony w szkołach polskich i dąży się do tego, aby nie różnił się od standardowej odmiany polszczyzny. Dla uczniów uczęszczających do polskich placówek edukacyjnych na obczyźnie, gdzie korzystają z (dalszego) kształcenia w zakresie przedmiotu język polski oraz innych, takich jak: historia, geografia, religia, polszczyzna jest więc językiem odziedziczonym, inaczej ojczystym jako drugim [Lipińska, Seretny, 2013, s. 3].

Inny stosowany w literaturze przedmiotu termin - język dziedziczony - wydaje się bardziej odpowiedni do sytuacji na Ukrainie, gdzie młodzież nie zawsze wynosi z domu dobrą znajomość polszczyzny (trudno więc właściwie mówić o jej odziedziczeniu), choć po starszych członkach rodziny, często dziadkach, ją dziedziczy [por. np. Zelins'ka, 2018, s. 63]. Dobrą znajomość języka polskiego dzieci i osoby młode zdobywają najczęściej w placówkach edukacyjnych. Są też takie dzieci, które od podstaw uczą się w szkołach języka polskiego² (ale nie jako obcego - czują bowiem więź z polszczyzną jako językiem swojej mniejszości narodowej). A ponieważ w pojęciu dziedziczenie zawiera się presupozycja ciągłości i trwania, to i termin język dziedziczony nie jest w analizowanej sytuacji najwłaściwszy. Lepszy wydaje się termin język przodków, gdyż obejmuje on swoim zakresem wszystkie grupy młodzieży polskiego pochodzenia, niezależnie od stopnia znajomości języka polskiego przed rozpoczęciem jego systematycznej nauki poza domem. Obecnie język przodków na Ukrainie ma bardzo wyraźne cechy bilingwizmu, gdyż wpływa na niego język ukraiński, a czasami też rosyjski (bezpośrednio lub za pośrednictwem ukraińskiego).

Podstawowym źródłem materiału badawczego użytego na potrzeby niniejszego artykułu stał się właśnie język młodzieży uczęszczającej do polskich szkół na Ukrainie (tzw. szkół sobotnich). Na potrzeby badań opracowano kilka typów ankiet. W ankiecie I 46 osób - uczniów szkół sobotnich - udzieliło odpowiedzi na pytania otwarte dotyczące ich świadomości z zakresu używania trzech typów zwrotów grzecznościowych ${ }^{3}$. W ankiecie II 238 respondentów - również uczniów placówek

${ }^{1}$ Por. też termin język familijny [Handke, 1995].

2 Tzw. nowi użytkownicy języków mniejszości, którzy nie wynieśli znajomości języka swojej mniejszości narodowej z domu, ale zaczęli uczyć się go poza rodziną [zob. np. Dołowy-Rybińska, 2017].

3 Były to następujące pytania: 1) „Jak myślisz, dlaczego na Ukrainie osoby polskiego pochodzenia w sytuacjach rozmów oficjalnych, publicznych zwracają się często do innych na 
edukacyjnych - zaznaczyło swoje odpowiedzi-reakcje na zaproponowaną sytuację komunikacyjną ${ }^{4}$. Z kolei w ankiecie III, przeprowadzonej wśród młodzieży szkolnej (82 osoby), sytuacje komunikacyjne dotyczyły wyłącznie składania gratulacji i życzeń (zaproponowano 15 takich sytuacji). Uwzględniono również wyniki stu ankiet wyboru wielokrotnego (IV) ${ }^{5}$ (wypełnionych tym razem przez respondentów w różnym wieku), które posłużyły jako jeden z pierwszych „sygnałów” do zorientowania się, które formy grzecznościowe sprawiają osobom polskiego pochodzenia na Ukrainie najwięcej kłopotów komunikacyjnych. Tak więc łącznie zbadano wyniki ankiet uzyskanych od 466 respondentów. W analizach uwzględniono także teksty uczniowskie - zarówno ustne, jak i pisane, oraz pisane przez przedstawicieli Polonii teksty z gazet polskojęzycznych ukazujących się na Ukrainie'.

Spośród form grzecznościowych do analizy wybrane zostały trzy rodzaje zwrotów czy zjawisk etykietalnych: zwracanie się do adresata na pan/pani + imię, np. pani Mario!, w sytuacji oficjalnego kontaktu językowego; wyrażanie gratulacji i życzeń za pomocą struktur zawierających performatywy witam i pozdrawiam lub słowa od nich pochodne, typu pozdrowienia czy witania, np. Witam z urodzinami!; nadużywanie słów pan/pani przed nazwą własną w strukturach referujących, realizowanych głównie w prasowych tekstach informacyjnych, np. Prezesem Izby zostat Jacek Piechota, byty minister gospodarki, a ze strony ukraińskiej pan Oleg Dubynin (,Kurier Galicyjski” 2010, nr 19(119)). Wybrano je ${ }^{7}$, ponieważ

pan/pani + imię, np. Pani Mario?”; 2) „Jak myślisz, dlaczego czasem, gdy na Ukrainie pisze się po polsku (np. w polskich gazetach) o ludziach, dodaje się słowo pan lub pani przed ich imieniem i nazwiskiem, np. Do Polski przyjechat prezydent Ukrainy pan Petro Poroszenko?”; 3) „Jak myślisz, dlaczego osoby polskiego pochodzenia na Ukrainie często mówią Witam! lub Pozdrawiam! w przypadku świąt, urodzin lub imienin?”.

4 Na przykład: „Jesteś uczniem szkoły sobotniej lub innej polskiej szkoły na Ukrainie. Twoja nauczycielka (Maria Kowalska) prowadzi lekcję. Zwróć się do niej”. Inne sytuacje komunikacyjne, które uwzględniono w niniejszych badaniach, dotyczyły składania gratulacji i życzeń.

5 Przykład testu wyboru: „W oficjalnym liście urzędowym, po zaznaczeniu danych nadawcy i odbiorcy, wpisujemy bezpośredni zwrot adresatywny w postaci: a) Szanowny Panie Wroński!, b) Szanowny Panie Jarosławie!, c) Szanowny Panie!, d) Szanowny Panie Jarosławie Wroński!”.

6 Przeanalizowano teksty następujących gazet polskiej mniejszości narodowej na Ukrainie: „Gazeta Lwowska”, „Kurier Galicyjski”, „Lwowskie Spotkania”, „Dziennik Kijowski”, „Mozaika Berdyczowska”, „Gazeta Polska”, „Słowo Polskie”, „Monitor Wołyński”, „Polonia Charkowa”, „Gazeta Polska Bukowiny”.

7 Wyłoniono je na podstawie: 1) wyników wspomnianej ankiety wyboru wielokrotnego (IV) przeprowadzonej wśród użytkowników polszczyzny przodków (w różnym wieku), która wskazała na zagadnienia grzecznościowe najbardziej problematyczne dla osób polskojęzycznych na Ukrainie; 2) obserwacji języka ustnego osób pochodzenia polskiego na Ukrainie (w różnym wieku);3) analizy form grzecznościowych używanych w gazetach polskiej mniejszości narodowej na Ukrainie; 4) badania typowych błędów w zakresie polskiej etykiety językowej, popełnianych 
reprezentują najbardziej typowe cechy dyferencjalne ${ }^{8}$ polskiej etykiety językowej realizowanej w polszczyźnie przodków na Ukrainie9 9

Rozważania na zaproponowany w tytule temat należy poprzedzić analizą kluczowego terminu świadomość językowa, który bywa różnie traktowany w poszczególnych źródłach. Przykładowo: Encyklopedia językoznawstwa ogólnego, definiując świadomość językową jako „zdolność formułowania sądów o wyrażeniach językowych (np. o ich poprawności czy walorach stylistycznych) i o stosunkach zachodzących między nimi (takich, jak synonimia, sprzeczność)", odsyła do zakresowo bliskiego terminu intuicja językowa. W tym znaczeniu świadomość językowa - w różnym stopniu rozwinięta - charakteryzuje każdego użytkownika języka [Polański, 2003, s. 590]. W Encyklopedii języka polskiego świadomość językową jako „ogół poglądów jednej osoby, grupy społecznej lub szerszej zbiorowości na język, a także ogół postaw wobec niego i emocji z nim związanych", dzieli się na:

1. wiedzę o języku (intuicyjną, szkolną, rzadziej naukowa), 2. kompetencję językową, czyli zdolność do właściwej selekcji środków językowych, adekwatnych do celu wypowiedzi, jej charakteru, stylu, adresata, oraz 3. ocenę ich akceptowalności fonetycznej, gramatycznej, logicznej, kulturowej itd., czyli poczucie językowe [Urbańczyk, Kucała, 1999, s. 394].

W literaturze przedmiotu proponuje się - ujęte w odpowiednich terminach - odróżnienie świadomości lingwistycznej od świadomości językowej. Pojęcie świadomość lingwistyczna nawiązuje do przytoczonego wcześniej pierwszego znaczenia zawartego w Encyklopedii języka polskiego, a termin świadomość językowa do drugiego i trzeciego znaczenia. Marian Bugajski określa świadomość lingwistyczną jako znajomość „zasad budowy i rozwoju języka oraz reguł dotyczących posługiwania się nim", a świadomość językową jako „używanie języka, z którego osoba posługująca się nim zdaje sobie sprawę, nawet jeśli brak jej językoznawczego przygotowania” [Bugajski, 2006, s. 48].

przez Ukraińców uczących się języka polskiego jako obcego; udowodniono bowiem, że większość błędów - nie tylko pragmalingwistycznych - w polszczyźnie przodków na Ukrainie i w języku polskim jako obcym jest wspólna jako skutek interferencyjnego wpływu wschodniosłowiańskiego.

8 Warto zauważyć, że badane zjawiska - z perspektywy normy ogólnopolskiej - mają różny status. Gratulacje i życzenia typu Witam z urodzinami! itp. są niepoprawne w języku polskim, dwa pozostałe typy zjawisk są poprawne, ale różnią się stopniem dystansu (Pani Mario!) lub uwarunkowaniem sytuacyjnym (pan prezydent; pan Oleg Dubynin).

9 Cechy swoiste polskiej grzeczności językowej na Ukrainie wyróżnia się na podstawie odniesienia do materiałów zawartych w monografiach i słownikach, a także w licznych artykułach o polskiej etykiecie językowej w kraju - np. pracach Małgorzaty Marcjanik [2002; 2014] oraz innych autorów. Uwzględniono też publikacje ukraińskich badaczy dotyczące grzeczności językowej na Ukrainie [np. Bohdan, 1998; Radewycz-Wynnyc'kyj, 2001; Skab, 2008]. 
Świadomość językowa zawiera zatem komponent kompetencyjny (por. znaczenie drugie w Encyklopedii języka polskiego) oraz komponent przekonaniowy (por. znaczenie trzecie). W definicjach świadomości językowej pochodzących z różnych źródeł naukowych jeden z tych komponentów może być bardziej eksponowany, por. np. kompetencyjny: „znajomość języka charakteryzująca jego użytkowników, pozwalająca im na swobodne władanie językiem ojczystym" [Bugajski, 2006, s. 47]. W przytoczonej na początku naszych rozważań definicji zawartej w Encyklopedii językoznawstwa ogólnego uwypukla się komponent ocen i sądów użytkowników na temat języka [Polański, 2003, s. 590]. Podobnie ujmuje świadomość językową Andrzej Markowski. Według niego jest to „ogół poglądów na język i sądów o języku, które są [...] zwerbalizowane i w miarę stałe" [Markowski, 2011, s. 94]. W specjalistycznych opracowaniach naukowych można odnaleźć jeszcze inne ujęcia świadomości językowej ${ }^{10}$.

$\mathrm{Z}$ pojęciem świadomości językowej w jej dwóch podstawowych aspektach - kompetencyjnym i przekonaniowym - wiąże się pojęcie świadomości normatywnej. Jest ona najbardziej tradycyjnie rozumianym wymiarem świadomości językowej [zob. np. Maćkowiak, 2012, s. 11-14]. Jak piszą Magdalena Steciąg i Marian Bugajski: ,Świadomość językowa tradycyjnie rozpatrywana jest w [...] ścisłej zależności od pojęcia normy językowej (wręcz jako świadomość normy [...]" [Steciagg, Bugajski, 2012, s. 5]. Osoba posługująca się językiem ma z jednej strony pewne przekonania na temat jego poprawności i stosowności w określonych użyciach (przy czym oceniać może zarówno język innych ludzi, jak i swój własny), z drugiej zaś sama - przez realizowany przez siebie język - przedstawia pewien stopień umiejętności i sprawności językowych. Właśnie z tych dwóch perspektyw analizowana jest dalej świadomość językowa/normatywna osób polskiego pochodzenia, mieszkających na Ukrainie i posługujących się polszczyzną. $Z$ ankiet proponujących reakcje na sytuacje komunikacyjne (II, III) oraz wielokrotnego wyboru (IV) wyłania się stopień kompetencji użytkowników w zakresie form grzecznościowych wybranych do analizy. Natomiast świadomość językowa/normatywna w aspekcie przekonaniowym badana jest na podstawie ankiety I, zawierającej pytania o przyczyny użyć określonych zwrotów językowych w badanym środowisku. $\mathrm{Z}$ odpowiedzi na te pytania można czerpać także pewne informacje o kompetencji użytkowników, a nawet - częściowo - o ich wiedzy na badany temat (czyli również o elementy świadomości lingwistycznej).

${ }^{10}$ Na przykład normatywne, opisowo-rejestrujące, psycholingwistyczne, socjolingwistyczne, kulturowo-antropologiczne [Maćkowiak, 2012], por. też przeciwstawienie świadomości językowej świadomościom: komunikacyjnej oraz dyskursywnej [Bugajski, Steciąg, 2012]. 


\section{ZWRACANIE SIE NA PAN/PANI + IMIE}

Ankieta wyboru wielokrotnego (IV) wykazała, że osoby polskiego pochodzenia na Ukrainie (w różnym wieku) traktują formę zwracania się na pan/pani + imię za uniwersalny zwrot grzecznościowy, nadający się do każdej sytuacji komunikacyjnej, w tym oficjalnej. Zauważmy, że ankieta jest skonstruowana w ten sposób, że zawiera stosowną do sytuacji formę (inną niż pan/pani + imię, np. prosze pani - do nauczycielki w szkole podstawowej, panie profesorze - do nauczyciela w szkole średniej, pani redaktor - do dziennikarki w studiu i inne). Mimo to niewłaściwa wersja zwracania się na pan/pani + imię bywa wybierana. Odpowiedź pan/pani + imię była najczęściej wybierana w sytuacji zwracania się do nauczycieli szkolnych, szczególnie jeśli chodzi o środowisko polskie na Ukrainie (por. wykresy 1 i 2, ilustrujące sytuacje, w których, zdaniem respondentów, stosowne jest zwracanie się na pan/pani + imię).

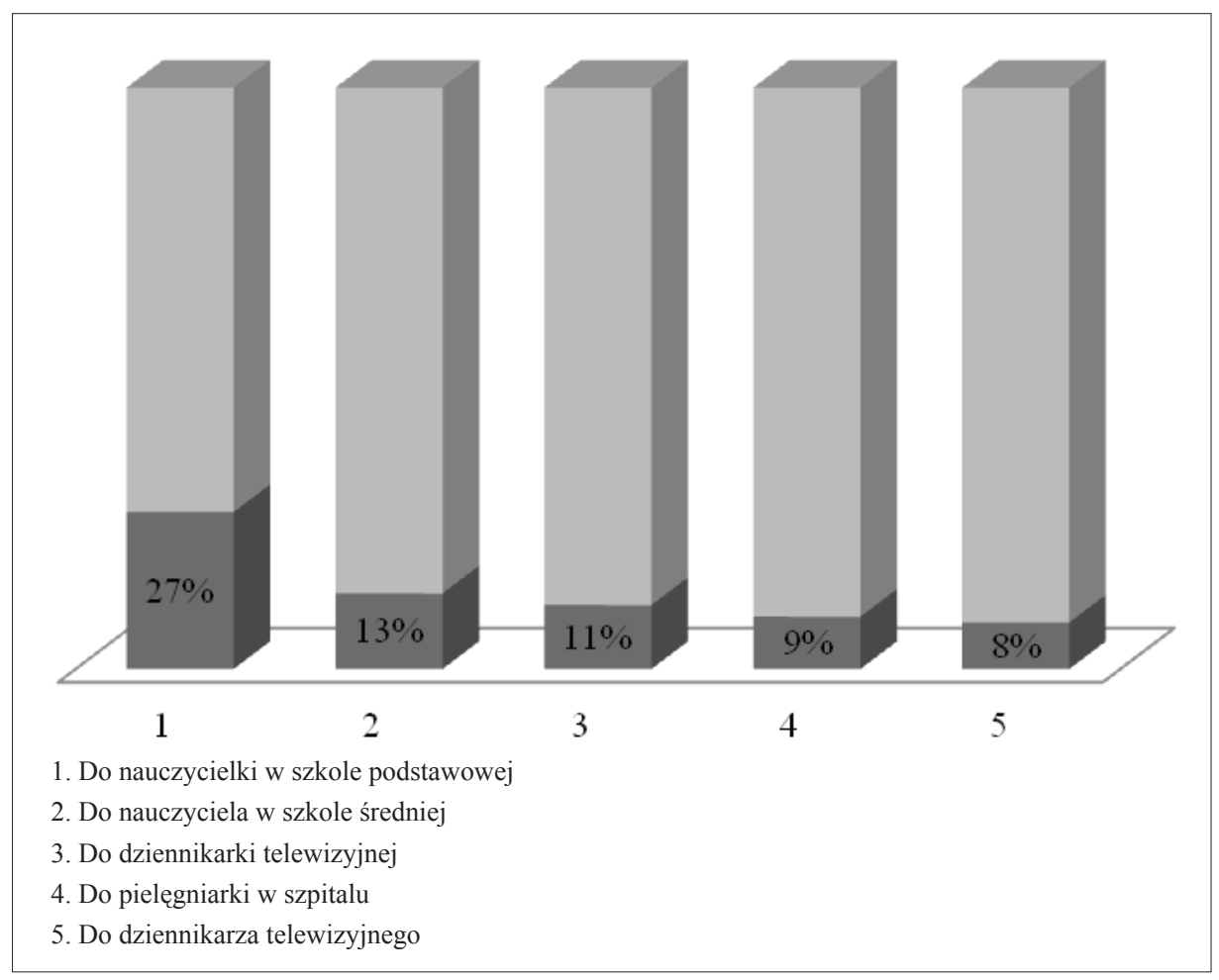

WYKRES 1. Zwracanie się na pan/pani + imię w realiach dotyczących Polski 


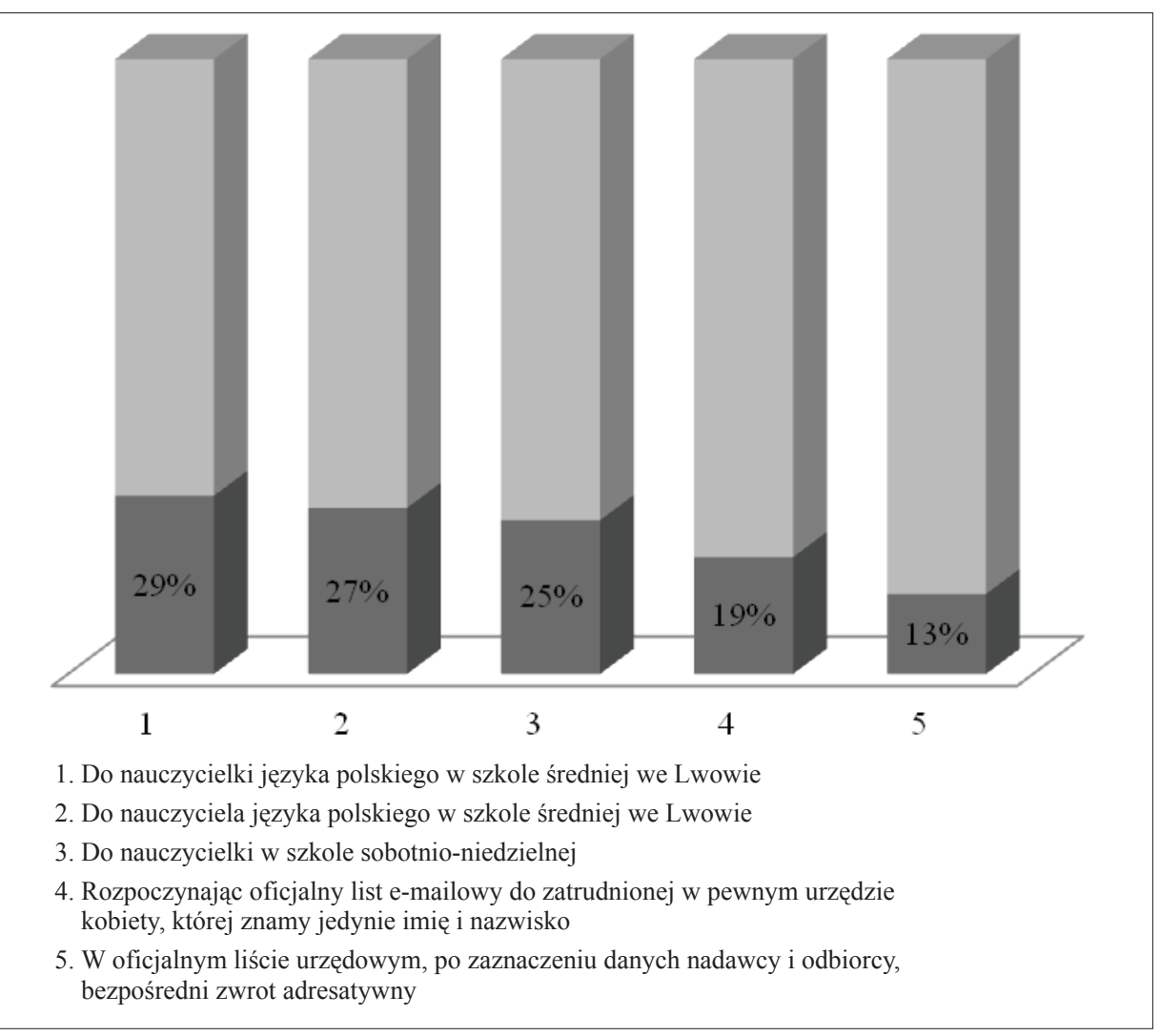

WYKRES 2. Zwracanie się na pan/pani + imię w środowisku polskim na Ukrainie

Wyniki ankiety IV świadczą o dość dużych brakach kompetencyjnych. Podkreślmy, że w ankiecie pytano o to, jak powinno się zwracać (a nie jak pan/pani się zwraca) w określonych sytuacjach. W związku z tym przewidziano odpowiedź odzwierciedlającą znajomość wzorca i niedopuszczającą innych motywów rzeczywistego używania określonych struktur (o czym mowa dalej). Jak widać, ta znajomość nie jest zadowalająca, gdyż respondent nie zawsze potrafi wybrać właściwą wersję spośród przytoczonych.

W ankiecie II, zawierającej pytania otwarte (a więc bez gotowych odpowiedzi), już zdecydowanie więcej, bo aż 42\% uczniów-respondentów (w 101 spośród 328 ankiet), zwróciło się do nauczycielki szkoły sobotniej pani Mario/pani Maria. Dane te dokładniej ilustrują stan świadomości językowej rozumianej w aspekcie 
kompetencyjnym niż ten wynikający z ankiety IV, gdyż respondentom nie narzuca się żadnych odpowiedzi ani nie podpowiada się wersji właściwej.

Można jednak założyć, że użytkownik polszczyzny przodków nie musi realizować dokładnie takiego samego skryptu kulturowego jak w polszczyźnie ogólnej, a może przyjąć normę obowiązującą w jego środowisku językowym ${ }^{11}$. Można bowiem zauważyć, że zarówno w ankiecie II, jak i w drugiej części ankiety IV (wykres 2), w których badana jest etykieta językowa realizowana w środowisku osób polskiego pochodzenia na Ukrainie, respondenci świadomie podają lub wybierają wersję pan/pani + imię. Motywem zaznaczenia tej właśnie formy adresatywnej może być na przykład uznanie jej stosowności w sytuacjach kontaktowania się w lokalnej wspólnocie komunikatywnej. Aby zgłębić możliwe motywacje tego typu, badanym uczniom zaproponowano udzielenie odpowiedzi na wspomniane wcześniej pytanie ankiety I: „Jak myślisz, dlaczego na Ukrainie osoby polskiego pochodzenia w sytuacjach rozmów oficjalnych, publicznych zwracają się do innych często na pan/pani + imię, np. Pani Mario!?".

Zakładamy, że rzeczywiste przyczyny użyć tego typu to z jednej strony - wspomniany brak kompetencji w zakresie normy ogólnopolskiej i wynikające z niego przekonanie, że adresatyw pan/pani + imię jest typowy dla polszczyzny realizowanej w kraju, a z drugiej - interferencyjne oddziaływanie dominującego języka ukraińskiego, ponieważ na Ukrainie - przynajmniej na zachodzie i w centrum - występuje odpowiedni zwrot ukraiński typu Пані Mapiє! (obok funkcjonującego od lat zwrotu adresatywnego typu imię + imię odojcowskie, np. Маріє Володимирівно!), który nie razi w sytuacjach oficjalnego kontaktu językowego w życiu społecznym Ukrainy. Wpływ tej struktury ukraińskiej na miejscową polszczyznę może być wzmocniony świadomością „polskości” słów pan, pani. Uchodzą one za typowo polskie ${ }^{12}$, a także za „zawsze grzeczne”.

${ }^{11}$ Można też uznać, że polszczyzna przodków ma swoją własną normę językową, odmienną od normy ogólnopolskiej [por. Kucała, 1998 i rozwój tej idei w: Krawczuk, 2012].

${ }^{12}$ Por. na przykład fragmenty tekstów pochodzących z gazet polonijnych, w których obok tytułu, imienia i nazwiska polskiego prezydenta jest słowo pan, a nie ma go przed tytułem, imieniem i nazwiskiem prezydenta ukraińskiego: 1) Президент Польщі мотивував це прийнятим нещуодавно рішенням Конституційного Суду Украӥни, який підтвердив право Леоніда Кучми претендувати на президентство втрете [...] За словами пана Кваснєвського [...] i ие також розуміс Леонід Кучма. Пан Кваснсвський виключив можливість [...] („Gazeta Polska" 2004, nr 1(41); 2) Oczywiście, na czele delegacji jest pan Prezydent RP Lech Kaczyński. [...] Z całej Ukrainy przybywa 350 gości oficjalnych, na czele z Prezydentem Wiktorem Juszczenka („Gazeta Lwowska” 2006, nr 18(354)). Por. podobne przeciwstawienie na przykładzie innych osób niż prezydenci państw: Potem ta ekspozycja wyjedzie na pół roku do Polski, najpierw do muzeum w Radomiu. Pan dyrektor Pulnar zadbat o strone finansowa. [...]-Kto jest autorem idei organi- 
Stąd, jak się wydaje, wynika mniejsze przywiązywanie wagi użytkowników do tego, którego wyrazu użyje się po pan - imienia, nazwiska czy rzeczownika tytularnego. Najważniejsze dla nich jest, aby struktura adresatywna zawierała zawsze - ich zdaniem - ,grzeczne”, dodające szacunku, typowo polskie słowo pan lub pani. Można też założyć, że jeśli użytkownik polszczyzny przodków zna ogólnopolską normę pragmatycznojęzykową, a mimo wszystko używa w sytuacjach oficjalnego kontaktowania się w ramach lokalnej wspólnoty zwrotów adresatywnych pan/pani + imię, to czyni to w celu zamanifestowania szczególnego, „ciepłego”, mniej dystansowego typu relacji w ramach wspólnoty-czegoś w rodzaju więzi wspólnotowej.

Przeprowadzona wśród uczniów ankieta I potwierdziła niektóre z tych założeń badawczych, a co ważniejsze - ukazała ich swoistą hierarchię w świadomości młodzieży.

Aspekt przekonaniowy świadomości językowej badanych uczniów w zakresie stosowania w sytuacjach oficjalnych adresatywu pan/pani + imię przedstawia się następująco (wykres 3):

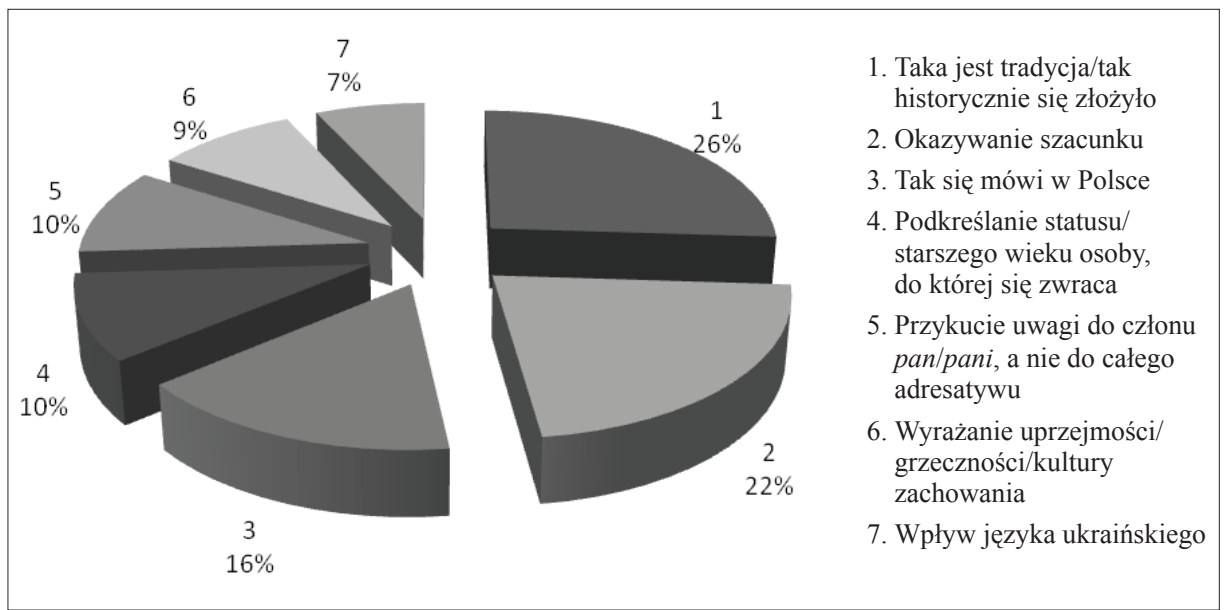

WYKRES 3. Przekonania badanych o używanym zwrocie adresatywnym pan/pani + imię

zacji tej wystawy? - Pan Pulnar z Radomia, ale „, mózgiem” wszystkiego, co tu widać, jest dyrektor Lwowskiej Galerii Sztuki Borys Woźnicki („Gazeta Lwowska” 2006, nr 13(349)). Por. także różnice w dwujęzycznych wersjach tego samego fragmentu tekstu: - Panie Juriju, zrealizowat Pan udany projekt - kalendarz „Poznaj naszych” zawierajacy wizerunki znanych Ukraińców / Ви реалізували успішний проект - календар ,, Знай наших” з ілюстраціями відомих українців („Monitor Wołyński” 2017, nr 6). 
Na trzech najwyższych pozycjach znalazły się motywacje:

1) tradycji używania tych zwrotów (nie zawsze jednak $z$ wypowiedzi ankietowanych można dowiedzieć się, czy chodzi o tradycję ogólnopolską, czy też miejscowa), np. Myśle, że tak mówili rodzice i dziadki ${ }^{13}$, że to jakiś zwyczaj (chłopiec, 15 lat, Nowy Rozdół);

2) ich wagi w okazywaniu szacunku dla adresata, np. Myślę, że to jest zwracanie się do nieznanej lub czcigodnej osoby (chłopiec, 17 lat, Borysław);

3) wzorowanie się na odpowiednich wzorcach językowo-kulturowych w Polsce, np. Ponieważ ludzie w Polsce robia tak samo (Użhorod).

Tak prezentuje się świadomość przekonaniowa młodych użytkowników polszczyzny przodków na Ukrainie.

Z badań ankietowych wynika, że młodzież polskiego pochodzenia na Ukrainie uważa zwracanie się na pan/pani + imię za typowo polskie (26\%), używane w Polsce (16\%) i raczej nie dostrzega w tym zakresie wpływu języka ukraińskiego (tylko 7\% wskazuje na możliwy wpływ ukraiński, np.: Myslie dla tego że to jest mowna tradycja mojego kraju (chłopiec, 15 lat, Użhorod)). Dodajmy, że użytkownicy często skupieni są na słowach pan lub pani jako typowo polskim sposobie zwracania się, nie przywiązując wagi do dalszego występowania imienia (10\%), np.: Bo w osób polskiego pochodzenia już tradycja taka jest: mówić na ,pan” czy „pani” (dziewczyna, 13 lat, Nowy Rozdół). Nie ma w wypowiedziach respondentów komentarzy, które wskazywałyby na ich świadomość specjalnej funkcji tych adresatywów - tworzenia szczególnej więzi wspólnotowej. Czesść ankietowanych uważa jednak, że badane zwroty grzecznościowe są tradycyjnie używane na tych terenach. Z ankiet wynika, że respondenci dostrzegają funkcjonalność tych adresatywów („okazywanie szacunku”-22\% + „wyrażanie uprzejmości/grzeczności/ kultury zachowania" - 9\%). Należy jednak podkreślić, że o funkcjonalności badanego adresatywu można mówić tylko wówczas, gdy dyskurs ograniczony jest do wewnątrzwspólnotowego. Przecież gdyby odbiorcą oficjalnego zwracania się na pan/pani + imię był adresat niebędący przedstawicielem badanej wspólnoty, forma taka, zawierająca imię, a nie na przykład rzeczownik tytularny, posłużyłaby do spoufalania relacji, a więc nie spełniłaby zamierzonej funkcji.

\section{WYRAZY PAN/PANI PRZED ANTROPONIMAMI W UŻYCIACH REFERUJĄCYCH}

Badania na temat konieczności używania słów pan, pani w strukturach referujących prasowych tekstów informacyjnych (typu wizytę złożyt pan Jan Kowalski)

${ }^{13}$ Wypowiedzi uczniowskie przytaczane są w oryginale, bez poprawiania odstępstw od norm językowych. 
wykazały, że ponad połowa (58\%) respondentów udzielających odpowiedzi na pytania ankiety wyboru ${ }^{14}$ uważa, że słowa te w podanych strukturach są potrzebne. Bardziej przekonujące pod względem świadomości jako kompetencji w tym zakresie są dane otrzymane na podstawie analizy polskojęzycznych tekstów prasowych ukazujących się na Ukrainie [Krawczuk, 2013] - używanie tego typu struktur jest najwyraźniejszą cechą grzecznościową polszczyzny gazet. Dostrzeżono, że autorzy tekstów, używając przed antroponimem słowa pan lub pani, czynią to z reguły, by wykazać się grzecznością, wyrazić szacunek wobec nazywanej osoby. Wydaje się, że schemat deprecjonowania przez stosowanie słów pan, pani przed nazwami własnymi osób znanych, o wysokim statusie ${ }^{15}$ nie jest w badanym środowisku znany.

Uzyskane na podstawie ankiety I dane o świadomości językowej w tym zakresie wskazują, że motywacją do używania słów pan, pani w składzie antroponimicznych struktur referujących jest przekonanie użytkowników, iż słowa te wyrażają szacunek. Dokładne wyniki zaprezentowano na wykresie 4.

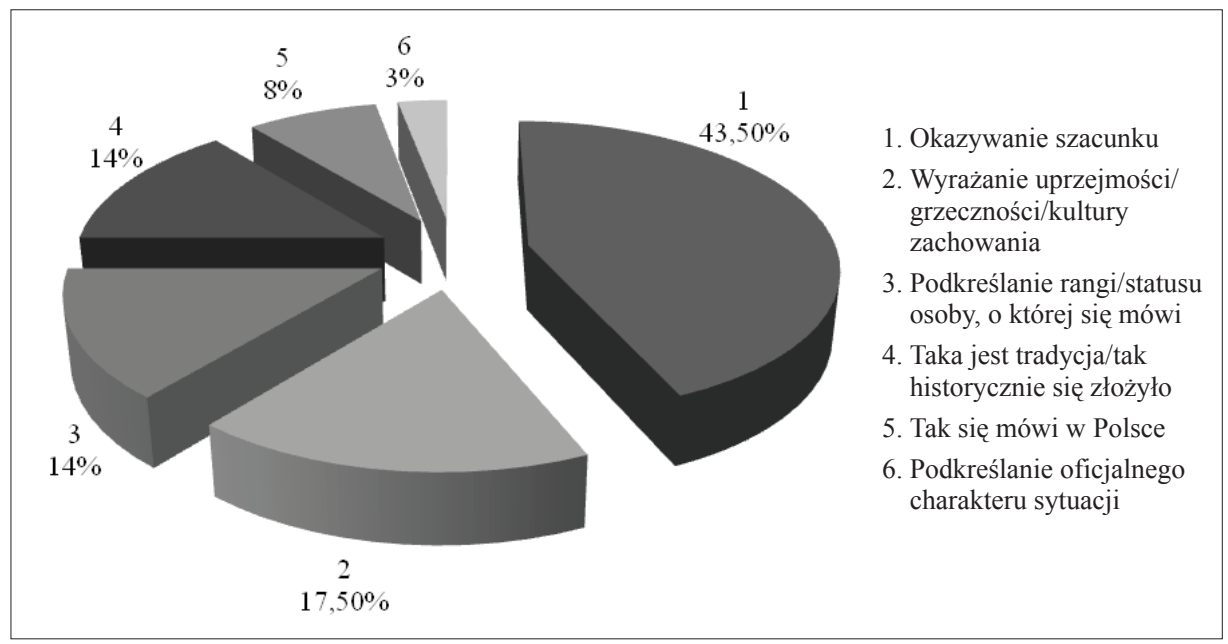

WYKRES 4. Przekonania badanych o użyciach referujących słów pan, pani

Tak jak w poprzednio analizowanym przykładzie $\mathrm{z}$ adresatywem zawierającym imię, w sytuacji użyć referujących słów pan/pani w prepozycji antroponimów

${ }^{14}$ Zaproponowano wybór spośród następujących wersji, które mogą pojawić się w informacyjnym tekście gazety: a) Pan prezydent Kowalski przebywa w Kijowie, b) Pan Jan Kowalski, prezydent Polski, przebywa w Kijowie, c) Jan Kowalski, pan prezydent, przebywa w Kijowie, d) Jan Kowalski, prezydent Polski, przebywa w Kijowie, e) Jan Kowalski przebywa w Kijowie.

${ }^{15}$ Pisze o tym wielu polskich badaczy, najszczegółowiej Marek Łaziński [2006]. 
można mieć wątpliwości dotyczące funkcjonalności stosowanych form językowych z perspektywy odbiorcy spoza wspólnoty. Wysoka ranga kryterium funkcjonalnego („okazywanie szacunku” - 43,5\% + „wyrażanie uprzejmości/ grzeczności/kultury zachowania" - 17,5\%) sprawdza się raczej tylko w środowisku polonijnym, nie zaś w społeczności językowej w Polsce, świadomej normy w tym zakresie ${ }^{16}$.

Zastanawiając się nad używaniem struktur referujących, badani - tak samo jak w sytuacji zwracania się na pan/pani + imię - przywiązują wagę do kluczowych słów pan i pani jako nośników konotacji grzeczności, szacunku, polskości, np.: Myślę, że to jest znak osoby kulturalnej (chłopiec, 17 lat, Borysław); To oznacza szacunek. Także to oznacza, że osoba jest bardzo szanowana (chłopiec, 15 lat, Borysław), Bo w Polsce ludzi zwracaja się do innych ludziej z szacunkiem. To jest zgodne z zasadami kultury języka polskiego (dziewczyna, 13 lat, Stryj). W użyciach tego typu dostrzegają także okazywanie szacunku dla ludzi szczególnie zasłużonych, o wysokim statusie społecznym (14\%, np. Dlatego że to oznacza szacunek do osoby, albo to, że ona ma jakaśs range (dziewczyna, 15 lat, Nowy Rozdół)), co jest jednak sprzeczne z normą grzecznościową w kraju. Im bowiem wyższy status referenta struktur antroponimicznych poprzedzonych wyrazem pan lub pani (ale bez tytułu funkcyjnego), tym bardziej deprymujący jest wydźwięk tych struktur [Łaziński, 2006, s. 89].

\section{WYRAZY WITAM, POZDRAWIAM W GRATULACJACH I ŻYCZENIACH}

Typową cechą grzeczności językowej w polszczyźnie na Ukrainie jest wyrażanie gratulacji i życzeń za pomocą autonomicznie występujących performatywów Witam!, Pozdrawiam! czy też zwrotów bardziej rozbudowanych, zawierających te słowa i rzeczowniki od nich pochodne (pozdrowienia, powitania, przywitania). Utrwalenie tego zwyczaju związane jest z wpływem języków wschodniosłowiańskich, w których wyrazy ukr. вітаю, поздоровляю, ros. поздравляю używane są najczęściej w sytuacjach, które odpowiadają polskim życzeniom i gratulacjom ${ }^{17}$.

${ }^{16}$ Nie wszyscy Polacy w kraju znają zasady normatywne dotyczące referujących użyć słów pan, pani przed antroponimami. Świadczą o tym na przykład pytania kierowane do internetowych poradni językowych.

${ }^{17}$ Oznaczają one 'gratulować' lub bywają używane na początku aktu życzeniowego jako jego wprowadzenie. Według danych leksykograficznych interesujące nas znaczenie ukraińskiego witać (вimamu) to 'wyrażać komuś poczucie radości, zadowolenia z okazji jakiegoś wydarzenia, sukcesu i in.', co raczej odpowiada znaczeniu polskiego wyrazu gratulować. Z części ilustracyjnej słownika wynika, że witać (вimamu) można nie tylko z okazji jakiegoś sukcesu lub wydarzenia, do którego przyczynił się solenizant, lecz także z okazji święta kalendarzowego. Ukraińskie gratulacje w formie 
$\mathrm{W}$ ankiecie wyboru wielokrotnego (IV) ${ }^{18}$ połowa respondentów wskazała zwroty zawierające słowa witam, pozdrawiam - oznacza to, że połowa ankietowanych nie radzi sobie z wyborem właściwej odpowiedzi spośród zaproponowanych.

W przypadku gdy zachodzi potrzeba samodzielnego wyprodukowania aktu gratulacyjnego lub życzeniowego (ankiety II i III, zawierające sytuacje, na które powinno się zareagować), badani uczniowie, mimo że w szkołach na pewno uczy się ich odpowiedniej normy pragmalingwistycznej, nadal mają kłopoty.

W trzech pytaniach ankiety II (258 respondentów) dotyczących gratulacji i życzeń odpowiedzi zawierających słowo witam lub pochodne (np. witania, powitania, przywitania) udzieliło 125 respondentów (52,5\%), odpowiedzi zawierających słowa pozdrawiam lub pochodne 25 respondentów $(10,5 \%)$, a odpowiedzi, które nie zawierały słów witam i pozdrawiam lub pochodnych, udzieliło 88 respondentów (37\%). Łącznie 63\% odpowiedzi zawierało słowa witam i pozdrawiam wobec $37 \%$ innych odpowiedzi (z reguły też niewłaściwych, np. podawano gratulacje $\mathrm{z}$ okazji imienin lub urodzin czy świąt kalendarzowych).

Ankieta III (82 respondentów) wykazała, że - przynajmniej w jednym spośród 15 pytań (a zdarzało się też, że we wszystkich) ankiety w całości poświęconej tematowi życzeń i gratulacji - słowa witam lub pochodnych użyło 55 respondentów (67\%), pozdrawiam lub pochodnych 12 respondentów $(15 \%)$, a witam i pozdrawiam lub pochodnych nie użyło 15 respondentów (18\%). Łącznie $82 \%$ ankietowanych użyło wyrazów witam i pozdrawiam, a $18 \%$ ich nie użyło. Prawie pięciokrotnie częściej występują wyrazy o rdzeniu -wit- niż te o rdzeniu -pozdr-.

witam mają zatem szerszy zakres niż gratulacje polskie. Rzeczownik odczasownikowy вітання jest definiowany jako 'ustne lub pisemne gratulacje (поздоровлення) lub życzenia zdrowia, sukcesów itp.' (Biłodid, 1970-1980, t. I, s. 686). Pozdrawiać (поздоровляти) mоżna zaś „,z okazji jakiegoś radosnego, przyjemnego wydarzenia (urodzin, ślubu, jubileuszu itd.)". Поздоровлення nadawane są ,z okazji jakiegoś radosnego, miłego wydarzenia (urodzin, ślubu, jubileuszu itd.)” (Biłodid, 1970-1980, t. V, s. 810-811). Jak widać, w języku ukraińskim granica między gratulacjami i życzeniami jest rozmyta, tych aktów mowy specjalnie się nie odróżnia, a oba ukraińskie performatywy вітаю, поздоровляю, tak jak rosyjski поздравляю, zawierają ponadto treść 'wyrazy pamięci'. To z kolei powoduje hybrydyzację gatunków w polszczyźnie funkcjonującej w otoczeniu ukraińskojęzycznym, np.: Gratuluję z urodzinami; Witam cię (co może oznaczać: 'pamiętam, że masz dzisiaj urodziny, cieszę się z tej okazji i życzę ci wszystkiego najlepszego'). Dokładniej na ten temat zob. Krawczuk [2018].

${ }^{18}$ Na przykład: a) Witam z okazji zdania egzaminu!; b) Gratuluję zdania egzaminu!; c) Witam ze zdaniem egzaminu!; d) Pozdrawiam ze zdanym egzaminem!; e) Zdałeś wreszcie ten egzamin, pozdrawiam!. 


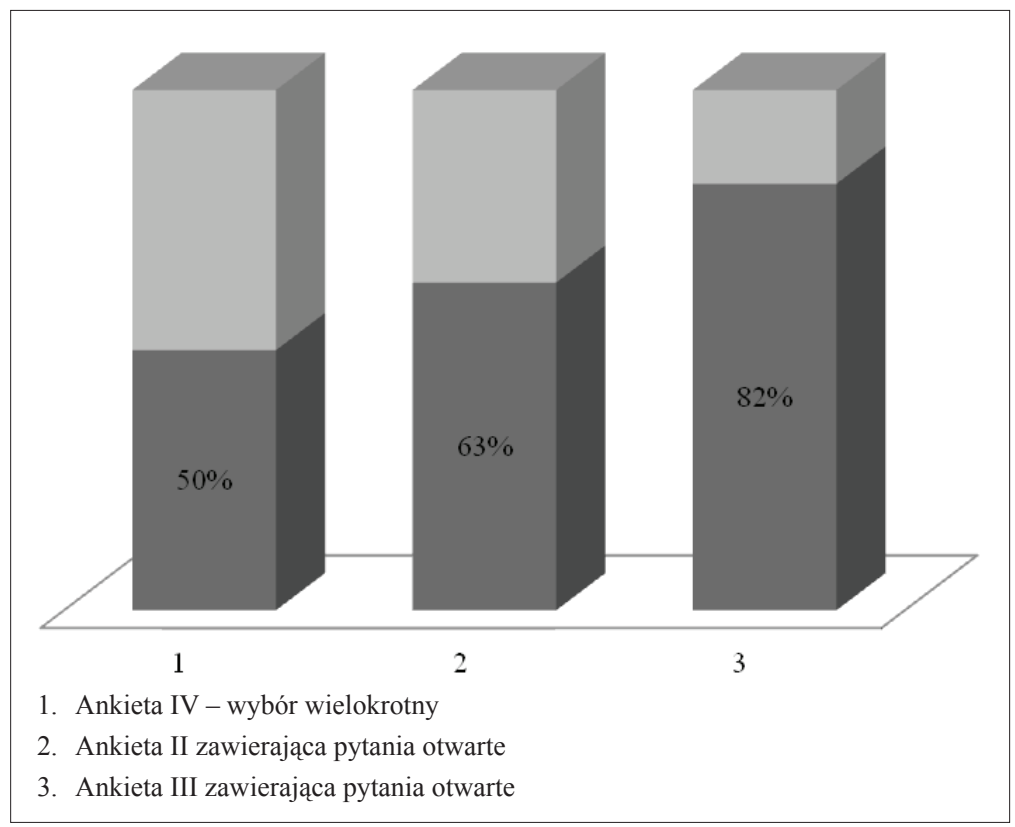

WYKRES 5. Składanie gratulacji i życzeń za pomocą słów witam, pozdrawiam na podstawie trzech ankiet

Uzyskane dane na temat świadomości językowej w aspekcie przekonaniowym (ankieta I) przemawiają za tym, że spośród trzech zaproponowanych zjawisk grzecznościowych respondenci mają największą świadomość normy ogólnopolskiej i wpływu na ich polszczyznę języka dominującego w odniesieniu do gratulacji i życzeń wyrażanych za pomocą struktur zawierających wyrazy witam i pozdrawiam. Większość ankietowanych uczniów zdaje sobie sprawę z tego, że realizowany w polszczyźnie na Ukrainie schemat odbiega od wzorca ogólnopolskiego i że przyczyną tego rozziewu jest wpływ języka ukraińskiego lub rosyjskiego, np.: Bo na Ukrainie jest ,Witaju”, a w Rosji „Pozdorovliaju”. A trzeba mówić „Składam życzenia” (dziewczyna, 14 lat, Nowy Rozdół); Dlatego, że na Ukrainie , Witam” $i$,Pozdrawiam” pisze się w sytuacji świąt, urodzin lub imienin, a w Polsce napszykład ,Witam Cię, Oksano! Jak się masz?” albo „Pozdrawiam z Ukrainy!” (dziewczyna, 15 lat, Nowy Rozdół). Szczegółowo ilustruje to wykres 6 . 


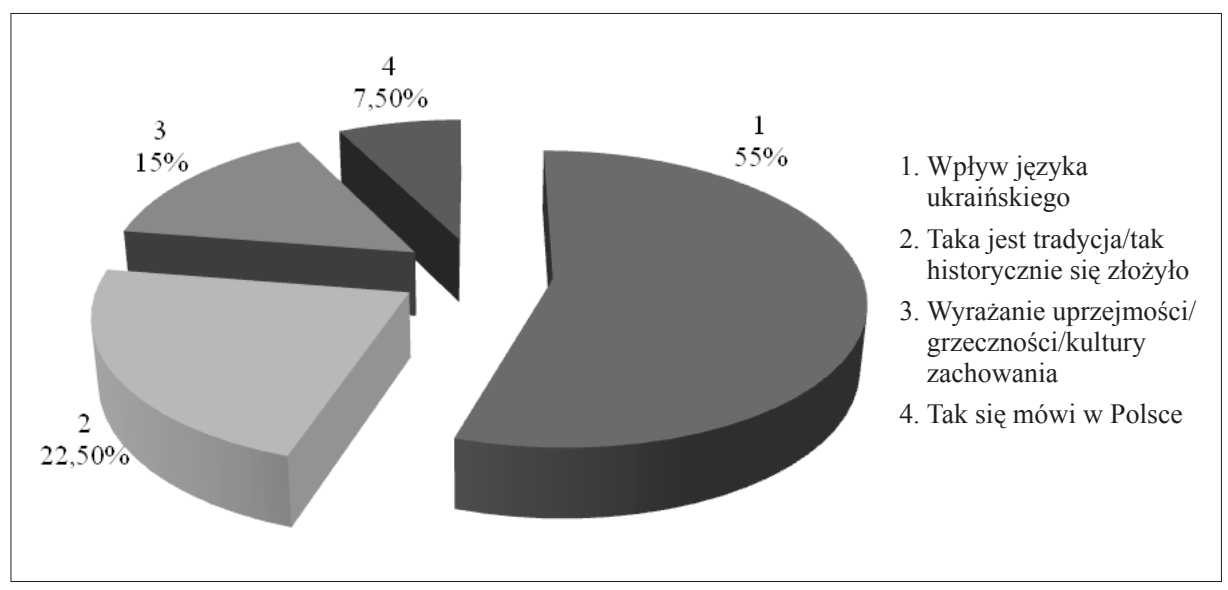

WYKRES 6. Przekonania badanych o używaniu słów witam, pozdrawiam jako gratulacji i życzeń

Mimo że duża liczba respondentów ma świadomość wpływu języka ukraińskiego (55\%), wielu badanych uważa jednak, że gratulacje i życzenia zawierające słowa witam i pozdrawiam są tradycyjne dla środowiska mniejszości polskiej na Ukrainie (22,5\%), np. Temu że na Ukrainie było dużo Polaków i ono przekazało się z pokolienia $w$ pokolienie (chłopiec, 14 lat, Stryj), oraz że są to wyrażenia grzeczne i stosowne (15\%), np.: Bo to jest mite (dziewczyna, 16 lat, Borysław); Aby dana osoba była zadowolona (dziewczyna, 16 lat, Borysław). Podobnie jak w analizowanych wcześniej sytuacjach grzecznościowych wysoką rangę kryterium funkcjonalnego można zaakceptować tylko $\mathrm{w}$ ramach środowiska polonijnego, nie zaś w sytuacji, gdy odbiorcą jest przedstawiciel społeczności językowej w Polsce.

Odpowiedź na pytanie, w jakim stopniu założenia badawcze i przedstawione w artykule wstępne wyniki analizy świadomości językowej użytkowników (głównie młodych) polszczyzny przodków na Ukrainie w zakresie stosowania wybranych form grzecznościowych odzwierciedlają rzeczywisty stan tej świadomości, mogą dać zakrojone na o wiele większą skalę badania socjolingwistyczne, szczególnie te ujawniające przekonaniowy aspekt świadomości językowej.

\section{ROZWIĄZANIA SKRÓTÓW}

ukr. - ukraiński

ros. - rosyjski 


\section{BIBLIOGRAFIA}

BıODID Iwan, red., 1970-1980, Słownyk ukrajins'koji mowy, t. I-II, Naukowa dumka, Kyjiw.

Bohdan Switłana, 1998, Mownyj etyket ukrajinciw: tradyciji i suczasnist', Ukrajins'kyj naukowo-wyrobnyczyj centr „Ridna mowa”, Kyjiw.

BugaJski Marian, 2006, Język w komunikowaniu, Wydawnictwo Naukowe PWN, Warszawa.

BugajSki Marian, Steciąg Magdalena, 2012, Świadomość językowa, komunikacyjna, dyskursywna, w: tychże, red., Świadomość językowa w komunikowaniu, Uniwersytet Zielonogórski, Zielona Góra, s. 29-39.

Dembowska-Wosik Iwona, 2011, Kultura jako czynnik motywujacy do nauki języka polskiego amerykańskich studentów o polskim pochodzeniu, „Acta Universitatis Lodziensis. Kształcenie Polonistyczne Cudzoziemców”, t. 18, s. $81-86$.

DoŁowy-RYBińsKa Nicole, 2017, „, Nikt za nas tego nie zrobi”. Praktyki językowe i kulturowe młodych aktywistów języków mniejszościowych Europy, Wydawnictwo Naukowe Uniwersytetu Mikołaja Kopernika, Torun.

DzIĘGIEL Ewa, 2017, Odmiany terytorialne i społeczne współczesnego języka polskiego na Ukrainie, „LingVaria”, t. XII, z. 2(24), s. 199-210.

HandKe Kwiryna, 1995, Polski język familijny. Opis zjawiska, Slawistyczny Ośrodek Wydawniczy Polskiej Akademii Nauk, Warszawa.

KRAWCZUK Ałła, 2012, Problemy normy języka polskiego w kraju i za granica (na Ukrainie), „Roczniki Humanistyczne”, t. LX, z. 6, s. 133-167.

KRAwczuK Ałła, 2013, Struktury referujace z wyrazami pan/pani w polskojęzycznej prasie na Ukrainie: grzeczność czy niegrzeczność?, „Acta Universitatis Lodziensis. Kształcenie Polonistyczne Cudzoziemców", t. 20, s. 119-129.

KRAWCZUK Ałła, 2018, „, Witam cię z urodzinami”: hybrydyzacja gatunków etykietalnych w polszczyźnie na Ukrainie, w: J. Tambor, red., Polonistyka na poczatku XXI wieku. Diagnozy. Koncepcje. Perspektywy, t. VI, Wydawnictwo Uniwersytetu Śląskiego, Katowice, s. 330-344.

KuCAŁA Marian, 1998, O polonijnych normach językowych, „Prace Filologiczne”, t. XLIII, s. 287-294.

LiPIŃSKa Ewa, Seretny Anna, 2012, Między językiem ojczystym a obcym. Nauczanie i uczenie siejęzyka odziedziczonego w chicagowskiej diasporze polonijnej, Księgarnia Akademicka, Kraków.

LipińsKa Ewa, Seretny Anna, 2013, Nie swój, lecz i nie obcy-język odziedziczony w perspektywie glottodydaktycznej, w: Młoda polska emigracja w UE jako 
przedmiot badań psychologicznych, socjologicznych i kulturowych, EuroEmigranci.PL, Kraków, 23-24 IX 2013, s. 1-16, http://www.euroemigranci. pl/dokumenty/pokonferencyjna/seretny_lipinska.pdf (dostęp: 24.11.2018).

LiPIŃSKa Ewa, SERETNy Anna, 2016, Język odziedziczony - polszczyzna pokoleń polonijnych, „Poradnik Językowy”, z. 10, s. 45-61.

ŁaZIŃSKI Marek, 2006, O panach i paniach. Polskie rzeczowniki tytularne i ich asymetria rodzajowo-ptciowa, Wydawnictwo Naukowe PWN, Warszawa.

Mас́кошіак Krzysztof, 2012, Świadomość językowa - problem definicji, w: M. Steciag, M. Bugajski, red., Świadomość językowa w komunikowaniu, Uniwersytet Zielonogórski, Zielona Góra, s. 9-27.

MarcjaniK Małgorzata, 2002, Polska grzeczność językowa, Wydawnictwo Akademii Świętokrzyskiej, Kielce.

MaRCJANIK Małgorzata, 2014, Stownik językowego savoir-vivre’u, Wydawnictwa Uniwersytetu Warszawskiego, Warszawa.

Markowski Andrzej, 2011, Świadomość językowa w „,Dziennikach” Marii Dabrowskiej (przyczynek do kształtowania się normy w polszczyźnie 1. połowy XX wieku), „Język Polski”, R. XCI, z. 2-3, s. 94-102.

Martowicz Anna, 2014, Dwujęzyczność w pytaniach i odpowiedziach, Association for the Promotion of Polish Language Abroad, Edynburg, http://www. polskamacierz.org/wp-content/uploads/2015/02/dwujezycznosc_w_pytaniach_i_odpowiedziach.pdf (dostęp: 15.08.2019).

PolaŃSKi Kazimierz, red., 2003, Encyklopedia językoznawstwa ogólnego, Zakład Narodowy im. Ossolińskich, Wrocław.

RADEWYCZ-WYNNYC'KYJ Jarosław, 2001, Etyket i kul'tura spiłkuwannia, Wydawnictwo „Społom”, L'wiw.

Sкав Marian, red., 2008, Ukrajins'ka systema naimenuwan' adresata mowlennia, „Ruta”, Czerniwci.

Steciąg Magdalena, Bugajski Marian, 2012, Wstęp, w: tychże, red., Świadomość językowa w komunikowaniu, Uniwersytet Zielonogórski, Zielona Góra, s. 5-6.

UrbańcZyK Stanisław, KuCAŁa Marian, red., 1999, Encyklopedia języka polskiego, Zakład Narodowy im. Ossolińskich, Wrocław.

ZeLIns'Ka Marija, 2018, Komunikatywna kompetencija mołodych nosijich pol's'koji mowy zachidnych obłastej Ukrajiny, Poswit, Drohobycz. 


\title{
Atta Kravchuk
}

\section{ŚWIADOMOŚĆ JĘZYKOWA OSÓB POLSKIEGO POCHODZENIA NA UKRAINIE W ZAKRESIE UŻYWANIA WYBRANYCH FORM GRZECZNOŚCIOWYCH}

\begin{abstract}
Streszczenie
W artykule przeanalizowano świadomość językową w zakresie używania wybranych form grzecznościowych w środowisku użytkowników języka polskiego jako odziedziczonego na Ukrainie. Świadomość językowa rozumiana jest z jednej strony jako kompetencja, a z drugiej jako przekonania na tematy języka. Oba te aspekty zostały uwzględnione w analizie czterech typów ankiet (466 respondentów) oraz tekstów ustnych i pisanych, tworzonych przez użytkowników badanej polszczyzny. Przeanalizowano trzy typy zwrotów grzecznościowych, które mają najwyraźniejsze cechy specyficzne funkcjonowania w polszczyźnie na Ukrainie w porównaniu z językiem ogólnopolskim: zwracanie się do adresata w sytuacji oficjalnej na pan/pani + imię, np. pani Mario!; wyrażanie gratulacji i życzeń za pomocą struktur zawierających performatywy witać i pozdrawiać, np. Witam z urodzinami!; nadużywanie słów pan/pani przed nazwą własną w strukturach referujących, realizowanych głównie w prasowych tekstach informacyjnych, np. Prezesem Izby zostat Jacek Piechota, byty minister gospodarki, a ze strony ukraińskiej pan Oleg Dubynin. Badania wykazały, że świadomość dotycząca wszystkich trzech typów struktur grzecznościowych jest dość słaba w aspekcie kompetencyjnym, natomiast w aspekcie przekonaniowym użytkownicy polszczyzny przodków najbardziej uświadamiają sobie niestosowność słów witam i pozdrawiam w gratulacjach i życzeniach. Ujawniono kilka rodzajów motywacji skłaniających użytkowników do używania trzech wspomnianych typów struktur.
\end{abstract}

\section{LANGUAGE AWARENESS OF PEOPLE OF POLISH DESCENT LIVING IN UKRAINE IN THE USE OF SOME POLITE FORMS}

\section{Summary}

The author of the article analyzes language awareness in the use of some polite forms by heritage Polish speakers in Ukraine. Language awareness is considered - on the one hand - as a competence, on the other as language beliefs. Both aspects were taken into account in the analysis of 4 types of questionnaires (466 respondents); oral and written texts created by speakers of studied Polish. Three types of polite phrases have been analyzed, which have the most distinct functioning specificity in the Polish language in Ukraine in comparison with the general Polish language: addressing the recipient in an official situation using pan/pani + imię, e.g. pani Mario!; expressing congratulations and wishes by means of structures containing performative verbs witać and pozdrawiać, e.g. Witam z urodzinami!; overusing of words pan/pani before a proper name in referential structures mainly in press information texts, e.g. Prezesem Izby zostat Jacek Piechota, byly minister gospodarki, a ze strony ukraińskiej pan Oleg Dubynin. The research shows that awareness as a competence is very low in all three types of polite structures, while in the aspect of belief heritage Polish speakers are most aware of the inaccuracy of the words witam and pozdrawiam in congratulations and wishes. Several types of motivation for the speakers to use these structures are revealed. 